1. MBBS, MS

Associate Professor

Department of Surgical Unit I

Peoples University of Medical \&

Health Science for Women Nawabshah.

2. MBBS, MS

Senior Registrar

Department of Surgical Unit II

Peoples University of Medical \&

Health Science for Women Nawabshah.

3. MBBS, MS

Assistant Professor

Department of Surgical Unit 2

Peoples University of Medical \&

Health Science for Women Nawabshah.

4. MBBS, FCPS

Associate Professor

Department of Surgical Unit 2

Peoples University of Medical \&

Health Sciences for Women Nawabshah.

5. MBBS, MS

Assistant Professor

Department of Surgical Unit 2

Peoples University of Medical \&

Health Sciences for Women Nawabshah.

6. MBBS, MS

Senior Registrar

Department of Surgical unit 2

Peoples University of Medical \&

Health Sciences for Women Nawabshah.

Correspondence Address:

Dr. Altaf Hussain Ghumro

Department of Surgical Unit I

Peoples University of Medical \&

Health Science for Women

Nawabshah.

altafghumro786@gmail.com

altafkhadim@yahoo.com

Article received on:

06/08/2018

Accepted for publication:

$10 / 12 / 2018$

Received after proof reading:

$26 / 03 / 2019$

\section{PERFORATED PEPTIC ULCER DISEASE;}

MODE OF PRESENTATION AND THE OUTCOME OF SURGICAL PROCEDURES ALONG WITH PROGNOSIS IN PATIENTS SUFFERING FROM PERFORATED PEPTIC ULCER DISEASE AT PMCH NAWABSHAH.

\begin{abstract}
Abdul Hakeem Jamali ${ }^{1}$, Altaf Hussain Ghumro ${ }^{2}$, Inayat Ali Zardari ${ }^{3}$, Mashooq Ali Khwaja ${ }^{4}$, Zulfiqar Ali Imtiaz Memon ${ }^{5}$, Imtiaz Ali Soomro ${ }^{6}$
\end{abstract}

ABSTRACT... Introduction: Peptic ulcer perforation is the most common surgical emergency and the leading cause of peritonitis with high morbidity and mortality in all age groups throughout world. It is more prevalent in developing countries than developed ones. Graham's Patch/omentopexy for duodenal perforation and simple closure along with tissue biopsy for the gastric perforation are the procedures of choice respectively. Objectives: To detect the mode of presentation and the outcomes of surgical procedures along with prognosis in patients suffering from perforated peptic ulcer. Study Design: Cross sectional study. Place and Duration of Study: Surgical Department of Peoples University of Medical \& Health Science for Women Nawabshah, From January 2016 to December 2017. Methodology: All patients were admitted through OPD/Emergency. Patients presented with peritonitis having history of peptic ulcer disease were studied. X Ray chest/ X Ray abdomen Erect showed pnemoperitonium. Laparotomy and primary repair along with biopsy for gastric perforation and graham's patch for duodenal perforations were performed. Results: In our study, total 52 patients were included. Male Female ratio was $3.5: 1.6$. Mean age was 49 years. Majority of patients presented in $5^{\text {th }}$ to $6^{\text {th }}$ decade of their life. In $96 \%$ cases abdominal pain was the $1^{\text {st }}$ symptom followed by vomiting and distension of abdomen. Different surgical procedures were performed and surgical site infection was the commonest complication in 37 (73\%) patients in our study. Conclusion: Primary closure and graham's patch are the best choice as surgical procedures for the cases of gastric and duodenal ulcer perforations respectively.

Key words: $\quad$ Graham's Patch, Omentopexy, Perforated Peptic Ulcer, Primary Repair.

Article Citation: Jamali AH, Ghumro AH, Zardari IA, Khwaja MA, Memon ZAI, Soomro IA. Perforated peptic ulcer disease; mode of presentation and the outcome of surgical procedures along with prognosis in patients suffering from perforated peptic ulcer disease at PMCH Nawabshah. Professional Med J 2019; 26(4):683-687. DOI: 10.29309/TPMJ/2019.26.04.3378

\section{INTRODUCTION}

Peptic ulcer perforation is the commonest emergencies of all gastrointestinal perforations after the typhoid/ tuberculous illeal perforations. ${ }^{1}$ Peptic ulcer is caused by infection produced by organism named Helicobacter Pylori, Non steroidal Anti inflammatory Drugs (NSAIDS), steroids, burns, stress, sepsis and multiple injuries also. ${ }^{2}$ NSAIDs not only cause perforation of peptic ulcer but also bleeding but the perforations induced by Steroids are still enigma. ${ }^{2}$ Gastric perforation is the result of an imbalance between the aggressive and protective elements of gastric mucosa. Duodenal perforation occurs due to erosion in normal duodenal mucosa that can be $0.5 \mathrm{~cm}$ deep and $3 \mathrm{~mm}$ wide. Duodenum is the second most common site of perforation in whole Gl system after colon. Mostly, the anterior surface of duodenum and lesser curvature of stomach develop perforations where as posterior surface of duodenum present with bleeding. Duodenal ulcer perforations are more common as compared to gastric one. Seldom is $4^{\text {th }}$ part of duodenum affected. Only $2-14 \%$ of peptic ulcer disease perforate while others heal by treatment. ${ }^{4}$ Chronic peptic ulcer usually present with episodes of dyspepsia for a few days before perforation occurs whereas acute ulcers perforate with no prior symptoms. The disease globally affects approximately 40 lakh people annually. Most of the patients affected are in their $4^{\text {th }}$ and $6^{\text {th }}$ decade of life. ${ }^{5}$

Edward crisp was the first to declare 50 cases of 
this disease but it was Johan Mikulicz Radecki (1850-1905 A.D) who invented the procedure of simple closure of this perforation. ${ }^{6}$

The moment of perforation is often identified by patient as sudden excruciating epigastric pain. ${ }^{7}$ The perforation in both organs causes the spread of their contents into the abdominal cavity. Patient presents with pain in whole abdomen with distension followed by vomiting then signs of peritonitis in later stages. In early presentation, pain is usually in upper abdomen, the contents leak into whole abdomen especially Right Illiac Fossa (RIF) simulating to acute appendicitis. Patients sometimes present with referred shoulder pain caused by Diaphragmatic irritation. ${ }^{8}$

Blood Complete Picture shows increased leukocytes but the diagnosis is made on X Ray chest showing gas under diaphragm in $75 \%$ patients only. Erect lateral chest radiography can detect pneumoperitonium upto $98 \%$ cases. Computed Tomography (CT) scan abdomen is considered to be the gold standard investigation. ${ }^{9}$ Ultrasonography of abdomen needs the best skill to detect pneumoperitonium and can miss the diagnosis. Radiological features of paralytic illeus may be seen in advanced cases. If pnemoperitoneum is absent on X Ray then doubt arises regarding the diagnosis and upper abdominal pain can mislead to acute pancreatitis because there is a moderate elevation of serum amylase even in $10-20 \%$ cases of perforated peptic ulcers. This dilemma is resolved by diagnostic peritoneal tap. If still no diagnosis is made, diagnostic laparoscopy is recommended. ${ }^{10}$

Many treatment options are available ranging from conservative to open/laparoscopic repair. However, the best option keeping in view the results is still indecisive. No consensus has still developed regarding the treatment options as the disease can be treated with conservative, simple closure of ulcer, closure with free omentum, closure of ulcer with use of pedicle omentum, definitive treatment with truncal vagotomy and drainage procedure or parietal cell vagotomy. ${ }^{11}$

The rationale of our study is to find out the mode of presentation and the results of surgical procedures in patients suffering from perforated peptic ulcer disease in our set up.

\section{PATIENTS AND METHODS}

This study included total 52 patients of acute abdomen resulting from perforated peptic ulcer (PPU) admitted at Surgical Department of $\mathrm{PMCH}$ Nawabshah from January 2016 to December 2017. Of them, 40 (76\%) were male and 12 (23\%) females.

All the patients of Peptic Ulcer Perforation (PPU) were admitted through OPD/Emergency department. Initial treatment was started by two wide bore I/V cannula to rehydrate the patient apart from catheterization and Ryle's tube. Investigations both biochemical and radiological were done. Accurate diagnosis was made on the basis of history, clinical examination and investigations including the biochemical and radiological were done. $X$ ray Chest/ Abdomen in upright position was taken that clearly showed pneumoperitonium as is shown in the figure below.

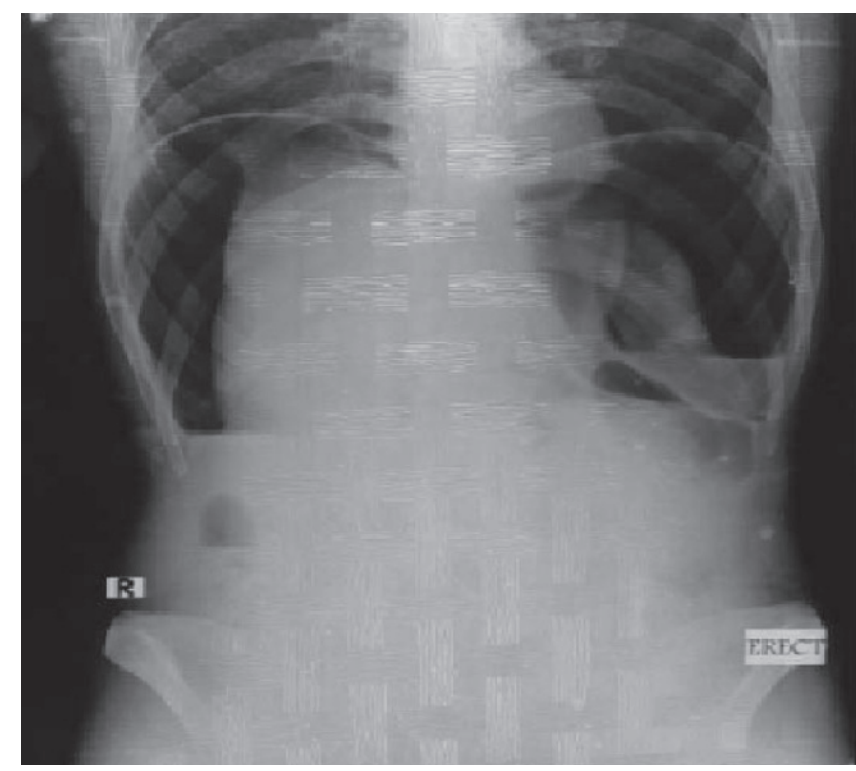

Cardiac and Anaesthesia fitness were obtained. Blood was arranged. Consent was taken and the patient was shifted to operation theater for the relevant procedure to be done. Prophylactic antibiotic at the time of induction of anaesthesia was given. Exploratory laparotomy was done. Graham's patch/Omentopexy for duodenal ulcer 
and simple closure for gastric perforation were done. Peritoneal cavity was washed with 6 to 10 litres of normal saline. Drain was kept and the cavity was closed in layers accordingly.

\section{RESULTS}

In our study, total 52 patients were operated. Of all, 40 males, 12 females with male female ratio of 3.5:1. Out of total patients, $65 \%$ had perforated duodenal ulcer and $35 \%$ had perforated gastric ulcer with duodenal and gastric ulcer ratio of 1.88:1. All patients had a single perforation.

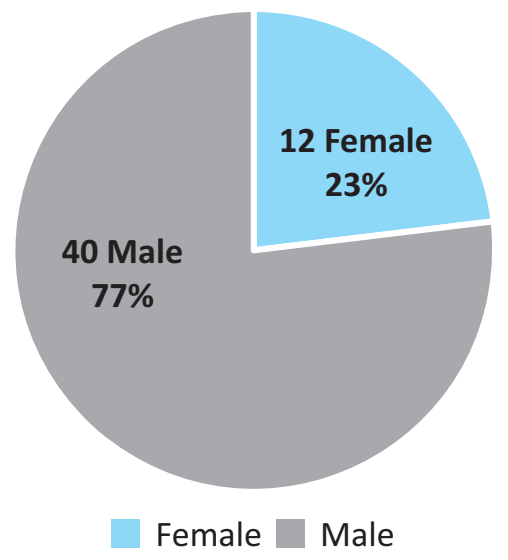

The age ranged between 17 to 95 years. The mean age was 49.99. The mean age for gastric ulcer perforation was 37.75 years and the mean age for duodenal ulcer was 55 years. Majority of patients 31 (59.61\%) had previous history of peptic ulcer disease and few taking even the H.Pylori Eradication Therapy and only 21 (40.38\%) had been taking NSAIDs, Steroids and anticancer therapy. Majority belonged to lower socioeconomic groups. Farmers were 21 (40.38\%), traders 6 (11.53\%) students 4 (7.69\%) teachers 3 (5.76\%).

\begin{tabular}{|c|l|c|c|}
\hline Sr. No & Occupation & $\begin{array}{c}\text { Number of } \\
\text { Patients }\end{array}$ & $\begin{array}{c}\text { Percentage } \\
\text { of Patient }\end{array}$ \\
\hline 1 & Farmers & 21 & $40.38 \%$ \\
\hline 2 & Traders & 6 & $11.33 \%$ \\
\hline 2 & Students & 4 & $7.69 \%$ \\
\hline 3 & Teachers & 3 & $5.76 \%$ \\
\hline 4 & Others & 18 & $34.61 \%$ \\
\hline Total & & 52 & $99.97 \%$ \\
\hline & & Table-I & \\
\hline
\end{tabular}

The commonest mode of presentation was pain in abdomen in all patients. Next common symptom was vomiting in 36 (69.23\%). Abdominal distention was in 32 (61.53\%). Fever occurred only in 16 $(30.76 \%)$. Gas under right dome of diaphgram was found in 47 (90.38\%) from plain chest or lateral decubitus radiographs. Risk factors identified include NSAID use in 19 (36.53\%), ingestion of herbal concoctions in $9(17.30 \%)$, dry fasting 3 (5.76\%) smoking in 3 (5.7\%).

\begin{tabular}{|c|l|c|c|}
\hline Sr. No & \multicolumn{1}{|c|}{$\begin{array}{c}\text { Clinical } \\
\text { Presentation }\end{array}$} & Frequency & Percentage \\
\hline 1 & Pain in Abdomen & 52 & $100 \%$ \\
\hline 2 & Vomiting & 36 & $69.23 \%$ \\
\hline 2 & Fever & 16 & $30.76 \%$ \\
\hline 3 & Constipation & 12 & $23.07 \%$ \\
\hline 4 & $\begin{array}{l}\text { Abdominal } \\
\text { distension }\end{array}$ & 47 & $90.38 \%$ \\
\hline & \multicolumn{2}{|c|}{ Table-II } \\
\hline
\end{tabular}

Postoperatively, 38 (73\%) developed infected wound, 9(17\%) developed wound dehiscence and $4(8 \%)$ came with pelvic abscess that was drained per rectally. Only 1 (2\%) developed low output faecal fistula that was managed conservatively.

\section{DISCUSSION}

In South Asia, ileum is the most common organ developing perforations caused by typhoid and tuberculous diseases. The next common organs developing perforations due to various other different reasons are Stomach and Duodenum. ${ }^{9}$ Various global studies show the increased incidence of gastric perforations but in our study the ratio of duodenal perforations is higher than gastric ones. ${ }^{10} \mathrm{~A}$ Study conducted in Rohilkhand region detected the prevalence of peptic ulcer perforations in $3^{\text {rd }}$ to $4^{\text {th }}$ decade of life but in our study age difference is noted. ${ }^{11}$ Most of the patients presented with perforations during $5^{\text {th }}$ and $6^{\text {th }}$ decades of their lives. ${ }^{2}$ Five years study in Irrua, Nigeria depicted same results as is of our study regarding the increased occurence in males. This nigerian study concluded that in their region there are more cases of gastric perforation than duodenal ones but in our study perforations of duodenum are found to be common. ${ }^{13,14}$ There 
is a great deal of racial and geographical variations in incidence of perforated peptic ulcer. ${ }^{15}$ Though, in the west its prevalence has decreased but still there is high mortality rate of the disease in Japan and United States but in our study mortality rate is somewhat decreased. ${ }^{16,17,18}$

In our study, 52 patients were operated for peptic ulcer perforations. This gives an average of 11 patients annually. Most of the patients had been suffering from ulcer for many years and a few patients developed ulcer by using drugs causing peptic ulcer disease. Mostly the poor people were affected from the disease especially the farmers, than traders as they used unhygienic food.

In every patient, pain was the main symptom then vomiting and abdominal distension. Fever was also the symptom but resulting from septicaemia. A few patientss developed constipation.

Unlike other areas of south Asia, our area presented depicted the picture of this disease altogether different in many aspects like site of perforations, male incidence etc.

Our study even in absence of emergency CT scan showed high detection of pneumoperitonium on plain chest and abdominal radiographs.

Our study showed a graham patch/omentopexy repair with acceptable results as compared to primary repair in cases of duodenal perforation. In case of gastric perforation, primary closure produced good results along with biopsy taken for histopathological purpose.

\section{CONCLUSION}

Duodenal perforation is more common as compared to gastric one in Sindh Pakistan and males are the most common victims as compared to females because of increased poverty and unhygienic conditions. The reason behind the late presentation of patients in tertiary care hospital is also the prevalence of poverty as they get symptomatic treatment by General Practitioners at local level. Despite the limited sources available even in our tertiary care hospital, the results of our study are optimistic. Graham's patch and simple closure of perforations produced excellent results with the lowest mortality rate. Only 1 case of postoperative leakage was noted that was also treated conservatively.

We suggest that if the incidence of the disease is to be decreased, the Government of Pakistan should take practical steps to decrease poverty, inflation and provide clean water to every citizen and improve hygiene.

Copyright@ 10 Dec, 2018.

\section{REFERENCES}

1. Alfred Cusheri. Acute gastroduodenal disorders. Essential Surgical Practice. $5^{\text {th }}$ edition 2015, 573-75.

2. Costa Simoes V, Santos B, Magalhães S, Faria G, Sousa Silva D, et al. (2014) Perforated duodenal diverticulum: Surgical treatment and literature review. Int j Surg Case Rep 5:547-550.

3. Soreide K, Thorsen K, Soreide JA (2014) Strategies to improve the outcome of emergency surgery for perforated peptic ulcer: Emergency surgery for perforated peptic ulcer. Br J Surg 101:51-64.

4. WHO, "World medicines situation," June 2015, http:// apps.who.int/medicinedocs/en/d/Js6160e/9.html.

5. Ana Karla de Sousa Almeida el el. Surgical therapeutic management of perforated peptic ulcer. International journal of Medical Rsearch and Health Sciences, 2016,5,3:57-61.

6. Sharad Seth, Keshav Kumar Agarwal. A Review of 51 cases of Duodenal Perforation in Rohilkhand Region. International journal of contemporary Medical Research. 1806-09.

7. Arora BK et el. Modified Grahams repair for peptic ulcer perforation: Reassessment study. Int Surg J.2017 May; 4(5):1667-1671.

8. Winder JA, Hill AG. The management of peptic ulcer. NZ Med J. 1995; 47-.

9. Nuhu A, Madziga AG, GaliBM. Acute perforated duodenal ulcer in Maiduguri. Internet J Surg. 2009; $21: 1$.

10. Bert leff M.J.O.E; Lange J.F. Perforated peptic ulcer disease: A review of history and treatment. Digestive Surgery. 2010; 27(3):161-169.

11. William N, Bullstrode C,O' Connel, P. Stomach and Duodenum in Bailey and Love's Short practice of surgery. $27^{\text {th }}$ edition London UK:CRC;2018. 
12. K. Thorsen et al. "Epidimiology of perforated peptic ulcer: Age and gender adjusted analysis of incidence and mortality" World Journal of Gastroenterology, Vol.19, no.3, pp.347-354,2013.

13. Shah FH, Mehta SG, Gandhi MD. Laparoscopic peptic ulcer perforation closure: The preferred choice. Ind J Surg. 2015; 77(2):403-6.

14. Satapathy MC, Dash D, Panda C. Modified graham's omentopexy in acute perforation of first part of duodenum; A tertiary level experience in South India. Saudi Surg J2013; 1:33-6.

15. Rao Mohan Vijaya S,. Sidharth O. A clinical study of duodenal ulcer perforation. Indian journal of Applied Research. 2014; 4:230-236.
16. Soro Kountele Gona et al. Postoperative morbidity and mortality of perforated peptic ulcer; retrospective cohort study of risk factors among black afericans in Cote d'Ivore. Gastroenterology Research and Practice vol 2016 Article ID 2640730, 7 pages.

17. Surapaneni $S, S$ R Reddy. A.VB. The perforation operation time interval; An important mortality indicator in peptic ulcer perforation. JCDR, 2013; 7:880-882.

18. Salomone Di Saverio et al. Diagnosis and treatment of perforated or bleeding peptic ulcers: 2013 WSES position paper World Journal of Emergency Surgery. 2014; 9:45.

\section{It is better to be feared than loved, if you cannot be both.}

\section{"Niccolo Machiavelli"}

\begin{tabular}{|c|c|c|c|}
\hline \multicolumn{4}{|c|}{ AUTHORSHIP AND CONTRIBUTION DECLARATION } \\
\hline Sr. \# & Author-s Full Name & Contribution to the paper & Author $=$ s Signature \\
\hline 1 & Abdul Hakeem Jamali & $\begin{array}{l}\text { Conception and design, Critical } \\
\text { revision of the article for important } \\
\text { intellectual content. }\end{array}$ & \\
\hline 2 & Altaf Hussain Ghumro & $\begin{array}{l}\text { Data collection, Revision of } \\
\text { manuscript, Statistical expertise. }\end{array}$ & \\
\hline 3 & Inayat Ali Zardari & $\begin{array}{l}\text { Critical revision of the article for } \\
\text { important intellectual content. }\end{array}$ & \\
\hline 4 & Mashooq Ali Khwaja & Statistical expertise, References. & \\
\hline 5 & $\begin{array}{l}\text { Zulfiqar Ali Imtiaz } \\
\text { Memon }\end{array}$ & $\begin{array}{l}\text { Conception and design, } \\
\text { References. }\end{array}$ & \\
\hline 6 & Imtiaz Ali Soomro & $\begin{array}{l}\text { Data collection, Revision of } \\
\text { manuscript. }\end{array}$ & Teuen \\
\hline
\end{tabular}

